\title{
Hispanic Women Entrepreneurs: Human Capital, Financial Capital, And Network Structure Relationships
}

Andrea E. Smith-Hunter, (Email: ahunter@siena.edu), Siena College Carol Venezio, (Email: venezio@siena.edu), Siena College

\begin{abstract}
In this paper, Hispanic women entrepreneurs are examined through a variety of perspectives. First, the analysis presented is an overview of miscellaneous characteristics, including financial information, age and marital status. The analysis continues with a look at the relationships between human capital, financial capital and network structures for the Hispanic women entrepreneurs. The study thus serves three purposes. First, it explores in depth areas of women entrepreneurship that are not always given an extensive focus; namely human capital and network structures. Second, it delineates how these dimensions are measured and are related to each other. Finally, it adds to the limited body of research on Hispanic women entrepreneurs, providing additional illumination for this sector.
\end{abstract}

\section{INTRODUCTION}

A

$s$ the area of women entrepreneurship gains momentum as a significant and relevant field of research, scholars need to address various areas that can facilitate a better understanding of the multiple dimensions that encompass the varied areas of women entrepreneurship. The lack of extensive research on Hispanic women entrepreneurs is striking. Two of the studies conducted on Hispanic women entrepreneurs showed predictable results when looked at from the perspective of the existing literature in the related area. Shim and Eastlick (1998) found their average age to be 35-54 years old, with older male counterparts, the authors also found that they were more likely to have operated smaller enterprises when compared to their male counterparts. The second study by Taniguchi (2002) found that Hispanic women had slower transition rates from the mainstream labor market into selfemployment, when compared to their white counterparts. This accelerated rate by the white women was based on their more advanced professional work experience, their more advanced overall work experience and their marital status (Taniguchi, 2002). In addition, the latter two factors were said to reduce the level of entry into self-employment by the Hispanic and African-American women (Taniguchi, 2002). Finally, the study's results showed that young children had no impact on the rate of entry into self-employment for white and African-American women but young children was shown to slow down the rate of entry into self-employment for Hispanic women (Taniguchi, 2002). Another study, conducted by Hout and Rosen (2000), has shown that the low rates of entry into self-employment for all Hispanic business owners, regardless of gender, can be attributed to them being less likely to be off-springs of selfemployed fathers.

In this paper, Hispanic women entrepreneurs are examined through a variety of perspectives. First, the analysis presented is an overview of miscellaneous characteristics, including financial information, age and marital status. The analysis continues with a look at the relationships between human capital, financial capital and network structures for the Hispanic women entrepreneurs. The study thus serves three purposes. First, it explores in depth areas of women entrepreneurship that are not always given an extensive focus; namely human capital and network structures. Second, it delineates how these dimensions are measured and are related to each other. Finally, it adds to the limited body of research on Hispanic women entrepreneurs, providing additional illumination for this sector. 


\section{LITERATURE REVIEW}

In addition to the limited literature review related to Hispanic women entrepreneurs presented above, three other related areas are explored in the following sections; they are presented in three succinct areas - namely human capital, financial capital and network structure literature.

\section{Human Capital Literature}

Based on the definition of entrepreneurship, it is obvious that the individual, as a focus, is the core of and thus the very essence of what an entrepreneur is. With that focus in mind, a look at entrepreneurship, absent a specific type of entrepreneurial venture with such factors as gender, race and geographic location of business - requires a look at the individual as a critical focus of any research in this area (Shaver and Scott, 1991; Stearns and Hill, 1996; Gartner, 1985). An integral part of the individualistic focus is a look at the definitions and dimensions of the term, human capital. Human capital has been defined as the propensity of a person or group to perform behavior that is valued from an income earning perspective by an organization or a society. The term human capital was originally used by Nobel economist Gary Becker, to refer to the stored valued of knowledge or skills of members of the workforce. The consensus among scholars is that human capital is critical to the formation and performance of entrepreneurial ventures (Smart, 1998).

Human Capital also refers to the knowledge, skills, competencies and attributes embodied in individuals that facilitate the creation of personal, social and economic well-being. This definition of human capital extends beyond those capital assets linked directly to productivity, to encompass factors that reflect the broader values associated with a well-educated population (Becker, 1993). The term "human capital" has traditionally been applied to educational attainment and includes the knowledge and skills that the labor force accumulates through formal instruction, training and experience (Becker, 1993). It has also been referred to in terms of the time, experience, knowledge and abilities of an individual household or a generation, which can be used in the production process. (Heckman, 2000). This definition relates to the income earning potential of individuals as workers in the mainstream labor market or the field of entrepreneurship.

A myriad of studies have taken a varied look at the dimensions that encompasses the growth of an individual's human capital potential. They range from educational attainment and work experience (Beggs, 1995; Raymn and Xie, 2000; Gimen, Folta, Cooper and Woo, 1997; Godoy, O’Neill, McSweeney and Wilkie, 2000; Gartner and Bhat, 2000) to include issues such as knowledge of the dominant language in the geographic region (Sanders and Nee, 1996; Pendakur and Pendakur, 2002) to the impact of parents' educational levels and background (Farkas, England, Vicknair and Kilbourne, 1997; Bates, 1990; Hendricks, 2001; Guiaitoli, 2000). The dimensions also extend to additional sources of learning that is obtained from contact with friends and associates (Heckman, 2000; Boucekkine, de la Croix and Licandro, 2002). In specific reference to entrepreneurs, it is felt by some authors that having parents who were themselves entrepreneurs, increases your human capital measure and also increases your chances of becoming an entrepreneur (Cooper and Dunkelberg, 1987).

Consistently the research studies indicate that an increase in the percentage of human capital that one possesses has a positive impact and thus denotes a positive relationship with one's income earning potential (Evans and Leighton, 1989; Greller and Stroh, 2002; Godoy et al, 2000) and that human capital differences are a key factor that results in labor market inequalities for various groups (Beggs, 1995). Others see human capital as an intangible asset, whose skills such as educational levels, knowledge and experience can be used for economic gains (Moses, 1998; Christou, 2001; Cianni and Romberger, 1995). Boyd's 1996 article points out that the undervaluing of disadvantaged groups' human capital potential, in particular minorities, has led to their income earning potential being given less rewards, compared to their more advantageous counterparts (Boyd, 1996). This argument has been echoed by Kazemipur and Halli (2001) who looked at immigrants in Canada through the use of Census Data and found that human capital factors were less rewarding for immigrants than for natives.

The current study zeroes in on the more pertinent human capital issues. More specifically, it gathers evidence regarding the women entrepreneurs' human capital potential by looking at such factors as their educational 
levels, their pre-business ownership experience (such as sales, marketing, accounting experience, seminars, programs attended) and organizational knowledge or experience. The objective is to determine whether these factors share a relationship with the entrepreneurs' network structure and to assess the kinds of impact, if any, they have on the economic successes of the women. The preceding section details all the potential primary elements of a woman entrepreneur's human capital dimensions. It represents an extensive list of all the possible human capital dimensions of a woman entrepreneur, much of this has been explored in the current study.

\section{Financial Capital Literature}

There remains a definitive link between one's access to financial capital and the economic success of any business (Finnerty and Krzystofik, 1986). While there are different ways to measure financial success for business owners (Begley and Boyd, 1987), studies have repeatedly shown that access to financial capital at the start-up stage and during the operation of a business is a key determinant to the expansion, sustainability and consistency of its' existence (Ong, 1981; Terpstra and Olson, 1993; O'Hare and Suggs, 1986). Possible sources of financial capital include, but are not limited to, the following: liquid assets (checking and saving accounts), credit lines, loans, capital leases (mortgages and motor vehicle loans), financial management services (transaction and cash management), owner loans, credit cards and trade credits (Bitler, Robb and Wolken, 2001). This section starts by drawing a general picture of the issues that are of a critical financial interest to entrepreneurs. Later in this paper, there is a specific focus on the financial capital dimensions that have been studied, illuminating such factors as the risks, discriminatory practices and other reasons for women entrepreneurs' predicament in obtaining and having continuous access to financial capital.

As noted previously, financial capital is one of the key ingredients enabling businesses to expand, remain viable and to become sustainable with long-term goals. While this is not necessarily the forum to undertake a comprehensive criticism of all the factors impacting the financial status of all groups of entrepreneurs, it is necessary to invoke a framework in which a context can be created to understand and evaluate the predicament faced by women entrepreneurs and a related disadvantaged group - minority entrepreneurs.

A number of studies have looked at the predicament of various groups of entrepreneurs' financial status and determined that a key factor is the lack of and the undermining of their human capital potential as it relates to their level of returns when it comes to access to financial capital (Loscocco and Leicht, 1993; Cressey, 1996; White, 1982). This has led to a continuous disadvantaged position both in the start-up stage and the operational stage of the business and it will continue to plague women entrepreneurs who choose to operate businesses. This argument has been extended and applied to the positions occupied by: international entrepreneurs (Chen, 1986; Stevenson, 1986), immigrant entrepreneurs (Wilson and Martin, 1982; Hoffman and Marger, 1991), minority entrepreneurs (Christopher, 1998; Horton and DeJong, 1991; Light, 1979; Van Auken and Horton, 1994; Scott, 1983; Bates, 1997; Bates, 1991), and black entrepreneurs (Russell, 1981; Bates, 1995b; Woodson, 1988; Bates, 1990; Bates and Osborne, 1979).

The lower returns and ultimately the lower financial gains of the previously mentioned disadvantaged groups has been attributable to: limited markets for their businesses, an inability of the business owners to collect on the debts due to their businesses, low financial returns on investment, low earnings of the business owners' clientele, racial discrimination, unpredictable business cycles, limited access to secured credit., limited demand for products and services and unfavorable commercial bank behavior (Christopher, 1998; Chen,1986; Hoffman and Marger, 1991; Woodson, 1988).

In a similar vein to the difficulties faced by immigrants, minority and small business owners, numerous studies cite the lack of access to financial capital as a key factor impacting women entrepreneurs in the operation of their businesses. Articles by Hurtado (1989), Ibarra (1993), Hustedde and Pulver (1992), Nelton (1999), Brotherton (1999), Lerner and Almor (2002) and Hisrich and Brush (1984) among others lament the fate of women entrepreneurs who lack the necessary access to financial capital to adequately sustain and develop their businesses. More specifically, Hisrich and Brush (1984) who looked at 468 women entrepreneurs found that although the majority (68\%) were highly educated, they persistently had problems trying to access financial capital, including being able to obtain lines of credit and securing loans with an adequate collateral base (Hisrich and Brush, 1984). 
The above findings have been echoed in articles by Collerette and Aubry (1990) in a parallel study in Canada and Lerner and Almor (2002) who looked at 220 Israeli female business owners. The latter articles have attributed lower access to financial capital as being the results of the types of industries that women entrepreneurs predominantly operated in. Industries such as retail and personal services, where the financial returns offered were lower than that of other industries (Collerette and Aubry, 1990; Lerner and Almor, 2002). The service and retail businesses are seen as attractive options for women entrepreneurs, because of the lower investments in start-up capital required to instigate the initial existence of the business (Hisrich and Brush, 1984; Pellegrino and Reece, 1982; Brush and Hisrich, 1991). However, these lower initial capital outlays will more than likely result in smaller enterprises and the limited access to capital will also prevent expansion efforts by the women entrepreneurs. Hundley (2001) used data from a sample of 659 self-employed men and women to conclude that the major differential between the earnings of the two groups is as a result of the differences in the type of industries they were concentrated in. The author went further to state that the lack of access to financial capital is partially explained by the low returns offered by the industries they choose to concentrate in, rather than discriminatory practices, per se, by banks and lending institutions (Hundley, 2001).

An expansion of this argument by Robinson-Jacobs (2002) indicates that it is only by moving into unchartered territories and non-traditional industries that have previously been underrepresented by women entrepreneurs can women make significant advances. The author further states that women entrepreneurs can earn economic returns that increase their borrowing potential for their business operations but that to do so requires taking these non-traditional routes (Robinson-Jacobs, 2002).

Discriminatory practices levied against women entrepreneurs seeking funds to start or continue the operation of their businesses has been documented by several authors (Riding and Swift, 1990; Brush and Hisrich, 1991; Hisrich and Brush, 1984; Charboneau, 1981; Neider, 1987). Charboneau (1981) stated in an article more than two decades ago that one of the biggest obstacles facing women entrepreneurs is the discrimination they suffer from the banking and finance communities. Later, Neider (1987) looked at the demographic characteristics and experiences of 52 female entrepreneurs from the state of Florida, concluding that credit discrimination by banks and major lending agencies was the major barriers for these female entrepreneurs (Neider, 1987). Some potential important areas in the genre of financial capital were presented in the preceding areas. It is important to keep this coverage in mind as we move on to discuss the network structure research literature.

\section{Network Structures Literature}

Putnam (1995) indicates that our social connections and civic engagements pervasively influence our public life as well as our private prospects. These social bonds are said to be essential to a group's success and a substantial stock of social trust is said to make life easier for participants in their community (Putnam, 1995; Henry, 2002). Nowhere is this concept and its resulting implications more critical than in the area of entrepreneurship. A number of studies have exalted the importance of the connections of entrepreneurs to others who can influence their progress (Wilkinson and Young, 2002; Hyden, 2001; Loscocco et al, 1991; Gassenheimer, Baucus and Baucus, 1996). With this backdrop in mind, the following section embarks on a discussion of the issues of network structures and its impact on one's income earning potential. The section begins with a comprehensive look at the definition of what is considered a network structure, especially as it applies to entrepreneurs.

Network structures can be defined as the formal and informal connections of overlapping organizational, family and social memberships that accounts for our level of success, the resources we have available to us to satisfy our needs, obligations and expectations (Hogan, 2001; Easter, 1996; Aldrich, Reese and Dubini, 1989; Coughlin and Thomas, 2002). It has been described as the "hidden hand of influence" that impacts the development of business markets (Hogan, 2001; Choi and Hong, 2002; Chung and Gibbons, 1997). The theory has its roots in the sociological world that speaks of one's social capital, which has been defined as the weaving of interpersonal relationships and values within families and their communities (Hogan, 2001). Information exchange and learning is said to take place in network structures (Chung and Gibbons, 1987). It looks at how someone is related to others in their families and communities as well as the type of relationships that are developed with these family and community members (Fukuyama, 2002; Van Horn and Harvey, 1998). It is also said to depend on people's ability to work together in groups through communication and cooperation and is determined by three key group influences: work, family and 
social life (Aldrich, Reese and Dubini, 1989). Network structure is also said to be of a formal nature (banks, lawyers, business organizations) as well as an informal (family, friends, associates) nature (Bailey and Waldinger, 1991; Low and Macmillan, 1988).

The key factor that makes the entrepreneurs' network structure so critical to their development and success is access to additional network structures. In essence, not only are entrepreneurs connected formally and informally through relationships with other individuals and sectors, but depending on the type of relationship, the potential is there for each of these individuals in the entrepreneur's "primary" network structure to, in turn, provide access to their own network structures, allowing the entrepreneur access to a "secondary" network structure. This can lead to a level of interconnected relationships for entrepreneurs through indirect sources (Lucas et al, 2001). The strength of each network link is said to be dependent on the amount of assistance provided to the entrepreneurs through these links. Therefore, there are strong network links and weak network links, depending on what type of access is available and what resources they are in turn linked to (Lucas et al, 2001; Fratoe, 1986; Low and Macmillan, 1988; Feagin and Imani, 1994).

It is important for individuals to seek groups of individuals through coordinated efforts for their locus of support, instead of operating in a vacuum. The dimension of one's network structure is said to include: family, friends, religious and work affiliations, banks, lending agencies, government agencies and associates. These connections in turn, are deemed to provide role models, training experiences, advice, financial support, sources of labor, clientele, business advice and contracts for market shares (Fratoe, 1986; Molm, Peterson and Takahashi, 2001). The role of weak or strong tied social networks has been particularly important in understanding how individuals are steered to opportunities and vice versa (Mier and Giloth, 1986).

Some of the important works on entrepreneurship and network structure have focused on immigrant entrepreneurship. Specifically, Marger (2001), Hyden (2001), Light, Bernard and Kim (1999) have indicated that social capital is a vital resource, enabling immigrant entrepreneurs to find their economic and social niches in the host society. Issues such as securing investment capital, finding labor to help in the business and acquiring information are highlighted as some of the potential benefits (Marger, 2001). These three sources of assistance are said to come mainly from the immigrant entrepreneurs' ethnic and family ties.

The benefits of having a lucrative network structure for immigrants cannot be over-emphasized. Recent studies by Hyden (2001) and Light, Bernard and Kim (1999) have looked at the benefits of networks as a viable source of opportunity for migrants in a host country because of their lack of knowledge regarding the new system and for co-ethnics in developing countries where resources are limited (Light et al, 1999). Hyden (2001) and Light et al (1999) also indicate that a viable network in the host country is able to help in the assimilation of new migrants regarding housing, jobs and business start-ups with less investments in terms of money, when compared with those who do not use a network structure. And there are three key reasons for the formation of these network structures or more specifically its relative complement, social capital, as provided by Hyden (2001). The author speaks of a class solidarity growing out of a common sense of being exploited, this has historically been viewed as a cause for collective actions (Hyden, 2001). Then, there is the "moral economy" argument put forward originally by James Scott, which states that, people whose traditional values are being threatened by modernization, get together to defend these values (Hyden, 2001). Finally, the cooperation that emanates from the presence of strong communal ties, helps foster the development of a para-public realm, often in conflict with the norms underpinning the civic public realm (Hyden, 2001). In essence, individuals who feel threatened and suffer from a sense of vulnerability will form into collective forces to overcome and develop themselves beyond their vulnerabilities.

In the labor market, women and minorities, like immigrants and other disadvantaged groups, share an emphatic relationship that would result in the former two groups also benefiting from a network structure. Employees in organizations are promoted based on their access to individuals in high level positions to individuals, which is said to be limited for disadvantaged groups, such as women and minorities (Monk-Turner, 1992; Bates, 1973; 1986; 1991; Cox, 1994). The limitations are said to be caused by the fact that different groups are embedded in various types of network structures that offer different levels of opportunities, values and benefits that others can provide them (Molm, Peterson and Takahashi, 2001). Thus, benefits obtained by various groups, affect and is affected by opportunities, and 
different access to power and resources presented by and to them. The relationships created by the network links are thus of a collaborative nature (Fukuyama, 2002) and are vital as links to the economic successes and outcomes. This is especially true for women entrepreneurs, whose mainstream labor market links might not have been as strong as their male or non-minority counterparts. This status is said to carry over when they enter the entrepreneurial world.

While a few studies have downplayed the importance of network structures and emphasized the importance of human and financial capital in entrepreneurial success (Bates, 1986; 1987; 1994), the vast majority emphasize the positive aspects of network structures and their resulting network links (Beech, 1997; Gassenheimer, Baucus and Baucus, 1996; Chung and Gibbons, 1997; Low and Macmillan, 1988). Entrepreneurs are also said to be able to use their network structures to obtain financial capital through the transfer of credit and financial wealth from one entrepreneurial offspring to another entrepreneurial offspring (Dunn and Hotz-Eakin, 2000; Steinmetz and Wright, 1989). In fact, as previously stated, having kin or a parent that is an entrepreneur is said to increase the likelihood of someone entering into an entrepreneurial venture (Scherer, Adams, Carley and Wiebe, 1989; Boyd, 1991; Covin and Slevin, 1994).

A few studies have shown that the network structures of men versus women are different, while others have shown that the network compilation exists for majority versus minority groups. Specifically, Renzulli, Aldrich and Moody (2000) used a sample of Research Triangle area business owners and potential owners to conclude that heterogeneous rather then homogeneous structures were advantageous. The authors also found that these differences were not significant enough to explain the differences between the male and the female entrepreneurs' success (Renzulli, Aldrich and Moody, 2000). Instead, the authors found that women's entrepreneurial networks consisted of a higher level of kin and that this factor was the key reason for the disadvantaged position (Renzulli, Aldrich and Moody, 2000). A previous study by Aldrich, Reese and Dubini (1989) using the same data source found that male and female entrepreneurs did indeed have different network structures, with women having mainly men in their network structures, whereas men had very little or no women in their network structures. This disadvantageous position of women's network structures versus that of their male counterparts is akin to the disadvantageous position of the minority women entrepreneurs when compared o their non-minority counterparts. The disadvantageous positions of minority entrepreneurial networks was confirmed in studies by Fratoe (1986), Fratoe, (1988) and Feagin and Imani (1994).

Authors who took a comprehensive look at the issues of network structures for women were: Moore and Buttner (1997), Inman (2000) and Coughlin and Thomas (2002). Moore and Buttner (1997) assessed how women entrepreneurs developed and sustained networks as they moved from corporate environments to entrepreneurial ventures. The authors borrowed from ideas proposed by others to define and assess the network structures of women entrepreneurs, identifying them as follows:

- $\quad$ The propensity to network (who connects with others).

- $\quad$ Network activity (number of people connected to and the time spent making contacts).

- $\quad$ Network density (degree to which an entrepreneur reaches beyond immediate friends and the actual size of their networks).

- $\quad$ Network intensity (number of years a member has known other members of their network and the frequency of their interaction).

The authors grounded their research assumptions based on two perspectives. That contact with others is important to the start-up and development of a business (Aldrich et al, 1987, as cited in Moore and Buttner, 1997). And that the growth of a business is significantly related to time spent developing contacts with the stakeholders to a business (Ostgaard and Birley, 1996, as cited in Moore and Buttner, 1997). Moore and Buttner (1997) concluded that an adequate network structure is essential to the profitability and economic success of business. The authors go further to state that network membership is expensive in terms of investment value in the time, energy and resources if an effective system for women entrepreneurs is to identify subgroups of network links in larger organizations that can ultimately comprise one's network structure (Moore and Buttner, 1997). 
Inman's (2000) study, one of the few who looked at women entrepreneurs across racial lines, also focused on network structures as a part of its analysis. The author looked at both strong network ties (such as family, friendship and community contacts), as well as weak network structures (such as affiliates of friends or families and institutions or organizations that provided little contact) and concluded that both set of ties were critical to the information gathering and knowledge creating process that women used to start their businesses (Inman, 2000). The author also observed that owners of small-scale businesses relied primarily on kin and friendship ties to help with business tasks, while larger and more professional owners hired full-time employees and larger service providers to assist them (Inman, 2000). The author also noted that African American women use their ties to learn occupational skills, while the European American (Whites) women were more likely to use their network ties to learn business skills (Inman, 2000). The basic information presented here on the network structure literature for women entrepreneurs culminates in a desire to look at the relationships between network structure and the two previously reviewed areas - human capital and financial capital.

\section{OBJECTIVES OF THIS STUDY}

The thesis of this paper is that there will be significant relationships for Hispanic women entrepreneurs for network structure and financial capital dimensions, network structure and human capital dimensions and also for human capital and financial capital dimensions. Accordingly, our goal is to apply correlation coefficient analyses to a data set of 43 Hispanic women entrepreneurs. By focusing on Hispanic women only, we can get a better sense of the factors impacting the various areas of this group of women entrepreneurs, than is possible in comparisons of women versus men, or for women across racial lines. Having eliminated gender and/or race as a key source of variation, we can look more carefully at the dynamics, which impact Hispanic women entrepreneurs. Our in-depth focus on this group of women is also an important reminder that there is tremendous variation among women entrepreneurs and that there is much to be learned even from a monolithic analysis. The implications regarding possible relationships from the literature review gives rise to a divergent set of hypotheses which this study seeks to investigate.

\section{SAMPLE FRAME}

One of the most reputable database firms in the United States, Dun and Bradstreet obtains information from millions of public and private businesses - many of which volunteer to be surveyed - as well as from trade tapes, trade associations, court records, government documents, inter-business publications, banks and other financial institutions. In the present study, Dun and Bradstreet (2003) data were used to build a sample frame that was stratified by geographic region, gender, industry type (using the Standard Industry Code), sales volume, number of employees, number of years in business and race. The enterprises included in this frame were located mainly in the following states, namely: Alabama, Arizona, California, Florida, Georgia, Illinois, Michigan, New Jersey, New York, Ohio, Oregon, Pennsylvania and Texas. In building the sample frame, no restrictions were placed on annual financial figures or number of employees. However, to be included, the businesses had to have been in existence for at least a year. Forty-three (43) Hispanic/Latina women responded to mailed questionnaires, representing a $43 \%$ response rate from a total of 100 business owners contacted.

\section{RESULTS OF ANALYSIS}

A look at Tables 1-3 provide some interesting descriptive results, namely that:

- $\quad$ Most of the businesses are in the retail trade or services industry.

- $\quad$ Florida is the state hosting the highest number of business owners in the sample.

- $\quad$ The businesses have been in operation for an average of 14 years.

- $\quad$ The business owners are on average 50 years old.

- $\quad$ Most of the business owners are married, college educated and have on average 2 children.

Correlation coefficient analyses were performed to assess the relationships between various human capital, network structure and financial capital dimensions. Correlation coefficients values measure the rate of correlation between two variables and indicates the level a change in one variable, impacts the change in another variable (Bailey, 
1994; Kerlinger, 1986). The value of a correlation coefficient can range from -1 to $a+1$ and is seen as either a negative value (indicating that a change in one value is likely to result in the opposite change in the other related variable) or a positive value (indicating that a change in one value results in a similar change in the other related variable). In the latter case, both changes can be positive or negative (Bailey, 1994). The following overview results looks at the general correlation coefficients between variables that were presented in the questionnaire sent to the women entrepreneurs.

It begins with a look at the relationships between human capital dimensions and difficulty in obtaining financial capital, difficulty in obtaining a bank loan, the amount of start-up capital and seeing going into business as the only alternative. Table 4 shows ten statistically significant results for these relationships. First, an increase in membership organizations and assistance from other sources, decreases the level of difficulty in obtaining financial capital (cc values of -0.350 and -0.293 respectively). Second, an increase in the number of years in business, the age of the business owner, the assistance from others sources, family members working in the business and membership in organizations decreases the level of difficulty of obtaining a bank loan (cc values of $-0.392,-0.353$, $0.379,-0.341$ and -0.366 respectively). Third, the older the business owner, the less start-up capital they had and the more assistance they received from others (cc value of -0.525 ), the less start-up capital they had (cc value of -0.420 ). Finally, the higher the business owner's educational level, the less likely they were to see going into business as their only alternative $(\mathrm{cc}$ value $=-0.427)$.

For the relationships between network structure dimensions and years in business or previous selfemployment, table 6 provides 2 statistically significant results. First, business owners who were more likely to have family members who were business owners were also more likely to have been in business for longer time periods (cc value of 0.306). Second, the more likely the business owners were to have friends working in the business, the more likely they were to have been previously self-employed (cc value of 0.342 ).

For the relationships between network structure dimensions and pre-business ownership experiences, table 7 provides ten statistically significant relationships. First, more school education resulted in less business assistance from family (cc value of - 0.321), while more education resulted in the business owners belonging to more membership organizations (cc value of 0.352). Second, more assistance from other sources and more membership organizations, also resulted in more attendance at seminars and programs (cc values of 0.405 and 0.368 respectively). Third, more friends working in the business was less likely to result in the business owners having hobby related experiences (- 0.398). Fourth, more prior supervisory experiences were more likely to result in the business owners seeking more start-up assistance from others (cc value of 0.319). Fifth, more prior accounting experiences, was also more likely to result in family members working in the business and more start-up assistance from others (cc values of 0.388 and 0.323 respectively). Finally, prior sales/marketing experiences was also more likely to result in friends more likely to work in the business and in the business owners obtaining more assistance from friends (cc values of 0.377 and 0.443 respectively).

For the relationships between network structure dimensions and measures of income, table 12 provides four statistically significant relationships. More start-up assistance from family, more start-up assistance from friends, having family members who are business owners, led to higher net profit and personal income figures (cc values of $0.329,0.309,0.362$ and 0.340 respectively).

For the relationships between human capital dimensions and measures of income, table 14 shows five statistically significant relationships. The results indicate that more start-up assistance from friends, as well as having prior supervisory experience and sales/marketing experience led to higher profits (cc values of $0.389,0.348$ and 0.393 respectively). Second, having friends who are business owners, led to higher net profits and personal income (cc values of 0.362 and 0.340 respectively).

\section{DISCUSSION}

The core questions guiding this study were whether there were relationships between human capital, network structures and financial capital dimensions for Hispanic women entrepreneurs. In striving to answer such questions, 
necessary precursor characteristics regarding the business owners and the businesses were also identified. Some of the results in this study were familiar to readers previously associated with the genre of women entrepreneurship. Namely that the current Hispanic women entrepreneurs were also concentrated in the retail and services industries, a finding that has been heavily documented by others (Humphreys and McClung, 1981; Hisrich and Brush, 1985; Pelligrino and Reece, 1982; Birley, 1989; Belcourt, 1990; Loscocco and Robinson, 1991; Loscocco et al, 1991; Devine, 1994a; Chaganti and Parasuraman, 1996; Lerner and Almor, 2002 and Watkins and Watkins, 1986). In addition, like others (DeCarlo and Lyons, 1979); Birley, Moss and Saunders, 1987; Burr and Strickland, 1992; Riding and Swift, 1990; Fischer, Reuber and Dyke, 1993; Chaganti and Parasuraman, 1996 and Brush, 1997), the current study found that the Hispanic women-owned businesses were small enterprise, with less than 10 employees and that they had operated for approximately 14 years. This latter finding is in contrast to most others on women entrepreneurs who found that the businesses had operated on average for 10 years or less (Buttner and Rosen, 1992; Moore and Buttner, 1997; Loscocco and Smith-Hunter, 2004; Smith-Hunter, 2003; Bowser, 1972).

In terms of more specific demographic issues, the Hispanic women entrepreneurs in the current study were mostly married, with children. In the former case, echoing results from (Danhauser, 1999; Olson, 1997; Furry and Lino, 1992 and Moore and Buttner, 1997) and in the latter case, echoing results from (Danhauser, 1999; Olson, 1997; Furry and Radhakrishna, 1992 and Brush and Hisrich, 1991). In the current context, assistance from others was shown to have positive influences on access to financial capital and in turn, financial successes for the Hispanic women entrepreneurs. The argument that can be developed from these findings is in keeping with those of others (Humphreys and McClung, 1981 and Model, 1985), who also found positive influences from members of one's network structure. In addition, similar to findings in the current study, Bates (1995a and 1995b) and others (Lerner and Almor, 2002; Model, 1985 and Christopher, 1998) also indicated that previously related work, industry and management experiences had positive effects on an entrepreneur's financial position. As anticipated, the results from the current study confirm what has been declared in others - that one's network structure and human capital dimensions are important factors in directly determining viability and financial success.

What is significant in the current context, is the look that has been taken on Hispanic women entrepreneurs an often unexplored area. Future studies could expand on the baby steps that have been traveled here to look further at these relationships across various races of women entrepreneurs and for an even richer analysis, a look simultaneously across racial and gender lines.

Table 1: Types of Businesses

\begin{tabular}{|c|c|c|}
\hline Types of Businesses & Number of Businesses & Percentage of Total (\%) \\
\hline Accounting Services & 3 & 9.0 \\
\hline Retail Clothing Services & 4 & 11.6 \\
\hline Beauty Services & 5 & 2.3 \\
\hline Automotive Services & 1 & 11.6 \\
\hline Consultant Services & 5 & 4.7 \\
\hline Home Furnishing & 2 & 2.3 \\
\hline Real Estate & 1 & 4.7 \\
\hline Computer and Software Sales & 2 & 4.7 \\
\hline Dental Services & 2 & 2.3 \\
\hline Grocery Store & 1 & 4.7 \\
\hline Health Care Services & 2 & 9.3 \\
\hline Janitorial/Cleaning Services & 4 & 2.3 \\
\hline Manufacturing - Retail products & 1 & 4.7 \\
\hline Massage Therapist & 2 & 4.7 \\
\hline Photography & 2 & 4.7 \\
\hline Restaurant & 2 & 4.7 \\
\hline Travel Agency & 2 & 4.7 \\
\hline Web Design & 2 & 100.0 \\
\hline Total & 43 & \\
\hline
\end{tabular}


Table 2: State Businesses Are Located In

\begin{tabular}{|c|c|c|}
\hline States & Number of Businesses & Percentage of Total (\%) \\
\hline Alabama & 1 & 2.3 \\
\hline Arizona & 1 & 2.3 \\
\hline California & 8 & 18.6 \\
\hline Florida & 10 & 23.3 \\
\hline Georgia & 4 & 9.3 \\
\hline Illinois & 2 & \\
\hline Michigan & 2 & \\
\hline New Jersey & 1 & \\
\hline New York & 6.7 \\
\hline Ohio & 3 & \\
\hline Oregon & 2.3 \\
\hline Pennsylvania & 2 & \\
\hline Texas & 14.0 \\
\hline Total & 2 & \\
\hline & 4.0 \\
\hline
\end{tabular}

Table 3: Characteristics of Hispanic Women Business Owners

\begin{tabular}{|c|c|}
\hline Types of Characteristics & Characteristics of Hispanic Women Business Owners \\
\hline Average Age of Business & 14.09 years \\
\hline Average Age of Business Owner & 50.51 years old \\
\hline Average Age of Business Owner When Started Business & 37.52 years old \\
\hline Average Start-Up Funds & $\$ 22,688$ \\
\hline Average Number of Employees & 6.12 Employees \\
\hline Average Number of Employees (Men) & 1.76 Employees \\
\hline Average Number of Employees (Women) & 4.37 Employees \\
\hline Average Number of Children & 2.07 Children \\
\hline Average Number of Organizational Memberships & 1.91 Organizations \\
\hline Sales Revenue & $\$ 604,588$ \\
\hline Net Profit & $\$ 94,911$ \\
\hline Personal Income & $\$ 91,749$ \\
\hline Marriage Rates & $60.5 \%$ of sample \\
\hline College Educated - Undergraduate/Graduate & $58.1 \%$ of sample \\
\hline Business Owners With Children & $81.4 \%$ of sample \\
\hline
\end{tabular}

$\mathrm{N}=43$ 
Table 4: Correlation Coefficients of Human Capital Dimensions and Other Dimensions

\begin{tabular}{|c|c|c|c|c|}
\hline Human Capital Dimensions & $\begin{array}{l}\text { Difficulty of Obtaining } \\
\text { Financial Capital }\end{array}$ & $\begin{array}{c}\text { Difficulty of Obtaining } \\
\text { a Bank Loan }\end{array}$ & $\begin{array}{r}\text { Star-Up } \\
\text { Capital }\end{array}$ & $\begin{array}{c}\text { Business As Only } \\
\text { Alternative }\end{array}$ \\
\hline Years In Business & -0.253 & $-0.392 * *$ & -0.029 & -0.104 \\
\hline Previous Self-Employment & 0.250 & -0.210 & 0.109 & 0.034 \\
\hline Educational Levels & -0.094 & -0.121 & 0.027 & $-0.427 *$ \\
\hline Age of Business Owner & -0.061 & $-0.353 * *$ & $-0.525^{*}$ & 0.133 \\
\hline Start-Up Assistance From Family & 0.137 & -0.239 & 0.246 & -0.159 \\
\hline Start-Up Assistance From Friends & 0.046 & -0.203 & 0.140 & 0.021 \\
\hline Start-Up Assistance From Others & 0.179 & -0.199 & $-0.420 *$ & -0.019 \\
\hline Business Assistance From Family & 0.247 & -0.203 & 0.214 & 0.048 \\
\hline Business Assistance From Friends & 0.134 & -0.215 & 0.104 & 0.080 \\
\hline Assistance From Other Sources & $-0.350 * *$ & $-0.379 * *$ & -0.225 & -0.022 \\
\hline $\begin{array}{l}\text { Friends Working in the Business } \\
\text { (Paid/Unpaid) }\end{array}$ & 0.234 & -0.061 & 0.191 & 0.199 \\
\hline $\begin{array}{l}\text { Family Working in the Business } \\
\text { (Paid/Unpaid) }\end{array}$ & 0.268 & $-0.341 * *$ & 0.106 & 0.230 \\
\hline Family Members Business Owners & 0.154 & 0.138 & 0.1850 & -0.168 \\
\hline Friends Business Owners & 0.241 & 0.093 & 0.241 & 0.092 \\
\hline Membership in Organizations & $-0.293^{* *}$ & $-0.366^{* *}$ & 0.125 & -0.210 \\
\hline PBOE: Job in Same Field & 0.008 & -0.243 & 0.067 & 0.031 \\
\hline PBOE: School Education & -0.039 & -0.121 & 0.035 & -0.287 \\
\hline PBOE: Seminars/Programs & -0.054 & -0.165 & -0.169 & -0.125 \\
\hline $\begin{array}{l}\text { PBOE: Hobby/Personal } \\
\text { Experience }\end{array}$ & -0.185 & 0.117 & -0.172 & -0.082 \\
\hline PBOE: Supervisory Experience & 0.242 & -0.031 & -0.131 & 0.070 \\
\hline PBOE: Accounting Experience & 0.148 & 0.112 & -0.199 & -0.056 \\
\hline $\begin{array}{l}\text { PBOE: Sales/Marketing } \\
\text { Experience }\end{array}$ & 0.176 & -0.039 & -0.200 & -0.076 \\
\hline
\end{tabular}

PBOE $=$ Pre-Business Ownership Experiences

$* * p=0.05 * \mathrm{p}=0.01$

Table 5: Correlation For Partners/Male Partners in Business and Difficulty in Obtaining Financial Capital/Obtaining Bank Loan

\begin{tabular}{|c|c|c|}
\hline & Correlations Coefficients for Partners & Correlations Coefficients for Male Partners \\
\hline Difficulty in Obtaining Financial Capital & -0.127 & -0.101 \\
\hline Difficulty in Obtaining a Bank Loan & 0.095 & -0.061 \\
\hline
\end{tabular}

$* * \mathrm{p}=0.05 * \mathrm{p}=0.01$

Table 6: Correlation Coefficients of Network

Structure Dimensions and Years in Business/Previous Self-Employment Experience

\begin{tabular}{|l|c|c|}
\hline \multicolumn{1}{|c|}{ Network Structure Dimensions } & Years in Business & Previous Self-Employment Experience \\
\hline Family Members Working in Business & -0.061 & 0.164 \\
\hline Friends Working In Business & -0.158 & $0.342^{* *}$ \\
\hline Start-Up Assistance From Family & 0.133 & 0.014 \\
\hline Start-Up Assistance From Friends & -0.003 & 0.171 \\
\hline Start-Up Assistance From Other Sources & -0.111 & 0.066 \\
\hline Business Assistance From Family & 0.011 & 0.021 \\
\hline Business Assistance From Friends & -0.075 & -0.047 \\
\hline Assistance From Other Sources & -0.141 & 0.173 \\
\hline Family Members Business Owners & $0.306^{*}$ & -0.014 \\
\hline Friends Business Owners & -0.112 & 0.112 \\
\hline Membership in Organizations & -0.105 & -0.092 \\
\hline Marital Status & 0.059 & 0.048 \\
\hline
\end{tabular}

$* * \mathrm{p}=0.05 \quad * \mathrm{p}=0.01$ 
Table 7: Correlation Coefficients of Network Structure Dimensions and Pre-Business Ownership Experience

\begin{tabular}{|c|c|c|c|c|c|c|c|}
\hline $\begin{array}{c}\text { Network Structure } \\
\text { Dimensions }\end{array}$ & $\begin{array}{c}\text { Job in Same } \\
\text { Field }\end{array}$ & $\begin{array}{c}\text { School } \\
\text { Education }\end{array}$ & $\begin{array}{l}\text { Seminars/ } \\
\text { Programs }\end{array}$ & Hobby & Supervisory & Accounting & $\begin{array}{c}\text { Sales/ } \\
\text { Marketing }\end{array}$ \\
\hline $\begin{array}{l}\text { Family Members } \\
\text { Working in Business }\end{array}$ & -0.125 & -0.186 & 0.010 & 0.155 & 0.282 & $0.388^{*}$ & 0.266 \\
\hline $\begin{array}{l}\text { Friends Working In } \\
\text { Business }\end{array}$ & 0.043 & -0.194 & 0.029 & $0.398 *$ & 0.244 & 0.209 & $0.377 *$ \\
\hline $\begin{array}{l}\text { Start-Up Assistance } \\
\text { From Family }\end{array}$ & -0.108 & -0.156 & -0.293 & 0.136 & -0.061 & -0.100 & -0.239 \\
\hline $\begin{array}{l}\text { Start-Up Assistance } \\
\text { From Friends }\end{array}$ & 0.200 & -0.070 & -0.025 & 0.012 & 0.100 & -0.055 & 0.071 \\
\hline $\begin{array}{l}\text { Start-Up Assistance } \\
\text { From Others }\end{array}$ & 0.205 & 0.221 & 0.333 & 0.287 & $0.319 * *$ & $0.323 * *$ & 0.204 \\
\hline $\begin{array}{l}\text { Business Assistance } \\
\text { From Family }\end{array}$ & -0.129 & $-0.321 * *$ & -0.239 & 0.087 & 0.032 & 0.237 & 0.033 \\
\hline $\begin{array}{l}\text { Business Assistance } \\
\text { From Friends }\end{array}$ & 0.046 & -0.192 & -0.034 & -0.257 & 0.281 & 0.211 & $0.443 *$ \\
\hline $\begin{array}{l}\text { Assistance From Other } \\
\text { Sources }\end{array}$ & 0.193 & 0.146 & $0.405^{*}$ & 0.036 & 0.261 & 0.118 & 0.219 \\
\hline $\begin{array}{l}\text { Family Members } \\
\text { Business Owners }\end{array}$ & -0.143 & 0.001 & -0.066 & -0.069 & 0.219 & 0.218 & 0.238 \\
\hline $\begin{array}{l}\text { Friends Business } \\
\text { Owners }\end{array}$ & 0.067 & 0.068 & -0.006 & -0.135 & 0.277 & 0.221 & 0.183 \\
\hline $\begin{array}{l}\text { Membership in } \\
\text { Organizations }\end{array}$ & 0.175 & $0.352 * *$ & $0.368 * *$ & 0.201 & 0.246 & 0.101 & 0.254 \\
\hline
\end{tabular}

$* * \mathrm{p}=0.05 * \mathrm{p}=0.01$

Table 8: Correlation Coefficients for Marital Status and Pre-Business Ownership Experiences

\begin{tabular}{|c|c|}
\hline Pre-Business Ownership Experiences & Correlation Coefficients of Marital Status for Hispanic Women Entrepreneurs \\
\hline Previous Self-Employment & 0.048 \\
\hline Job in the Same Field & 0.148 \\
\hline School Education & -0.069 \\
\hline Seminars, Programs & 0.167 \\
\hline Hobby/Personal Experiences & 0.002 \\
\hline Supervisory Experiences & 0.116 \\
\hline Accounting Experiences & 0.072 \\
\hline Sales/Marketing Experiences & 0.187 \\
\hline$* \mathrm{p}=0.05 * \mathrm{p}=0.01$ &
\end{tabular}

$* * \mathrm{p}=0.05 * \mathrm{p}=0.01$

Table 9: Correlation Coefficients For Difficulty in Obtaining Financial Capital and Bank Loan

\begin{tabular}{|c|c|}
\hline Variables & Correlation Coefficients \\
\hline Difficulty in Obtaining Financial Capital and Bank Loan & $0.668 *$ \\
\hline$* \mathrm{p}=0.05 * \mathrm{p}=0.01$ &
\end{tabular}

Table 10: Correlation Coefficients For Business Location

(Home/ Commercial Office) and Difficulty in Obtaining Financial Capital/Obtaining Bank Loan

\begin{tabular}{|c|c|}
\hline Variables & Correlations Coefficients \\
\hline Difficulty in Obtaining Financial Capital & 0.248 \\
\hline Difficulty in Obtaining a Bank Loan & 0.041 \\
\hline$* * \mathrm{p}=0.05 * \mathrm{p}=0.01$ &
\end{tabular}


Table 11: Correlation Coefficients For Type of Business and Difficulty in Obtaining Financial Capital/Obtaining Bank Loan

\begin{tabular}{|c|c|}
\hline Variables & Correlations Coefficients (Minorities) \\
\hline Difficulty in Obtaining Financial Capital (Sole Proprietorship) & -0.021 \\
\hline Difficulty in Obtaining Financial Capital (Partnership/Corporation) & 0.204 \\
\hline Difficulty in Obtaining a bank Loan (Sole Proprietorship) & 0.123 \\
\hline Difficulty in Obtaining a Bank Loan (Partnership/Corporation) & -0.033 \\
\hline
\end{tabular}

$* * \mathrm{p}=0.05 * \mathrm{p}=0.01$

Table 12: Correlation Coefficients of Network Structure Dimensions and Measures of Income

\begin{tabular}{|c|c|c|c|}
\hline Network Structure Dimensions & Sales Income & Net Profit & Personal Income \\
\hline Family Members Working in Business & -0.079 & 0.271 & 0.236 \\
\hline Friends Working In Business & 0.277 & 0.043 & 0.123 \\
\hline Start-Up Assistance From Family & -0.062 & $0.329^{* *}$ & 0.227 \\
\hline Start-Up Assistance From Friends & 0.132 & $0.309^{* *}$ & 0.217 \\
\hline Start-Up Assistance From Others & -0.271 & 0.088 & 0.090 \\
\hline Business Assistance From Family & -0.050 & 0.066 & 0.096 \\
\hline Business Assistance From Friends & 0.013 & 0.199 & 0.140 \\
\hline Assistance From Other Sources & -0.122 & 0.033 & -0.073 \\
\hline Family Members Business Owners & -0.042 & $0.362^{* *}$ & $0.340^{* *}$ \\
\hline Friends Business Owners & -0.008 & 0.262 & 0.230 \\
\hline Membership in Organizations & 0.007 & 0.045 & -0.027 \\
\hline Number of Organizations & -0.079 & -0.124 & -0.090 \\
\hline
\end{tabular}

$* * \mathrm{p}=0.05 \quad * \mathrm{p}=0.01$

Table 13: Correlation Coefficients of Measures of Income and Difficulty in Obtaining Financial Capital

\begin{tabular}{|c|c|c|c|c|}
\hline Measures Of Income & Financial Capital & Bank Loan & Start-Up Capital & Business Location \\
\hline Sales/Gross Revenue & -0.145 & 0.241 & -0.098 & 0.225 \\
\hline Net Profit & 0.091 & 0.180 & -0.073 & 0.118 \\
\hline Personal Income & 0.058 & 0.132 & -0.083 & 0.202 \\
\hline
\end{tabular}

$* * p=0.05 \quad * p=0.01$ 
Table 14: Correlation Coefficients of Human Capital Dimensions and Measures Of Income

\begin{tabular}{|l|c|c|c|}
\hline \multicolumn{1}{|c|}{ Human Capital Dimensions } & Sales/Gross Revenue & Net Profit & Personal Income \\
\hline Years In Business & -0.114 & -0.110 & 0.049 \\
\hline Previous Self-Employment & 0.285 & 0.207 & 0.123 \\
\hline Educational Levels & 0.156 & -0.001 & 0.024 \\
\hline Age of Business Owner & -0.085 & 0.170 & 0.194 \\
\hline Start-Up Assistance From Family & -0.062 & 0.043 & 0.123 \\
\hline Start-Up Assistance From Friends & 0.132 & $0.389^{* *}$ & 0.227 \\
\hline Start-Up Assistance From Others & -0.271 & 0.088 & 0.090 \\
\hline Amount of Start-Up Capital & -0.015 & -0.028 & -0.054 \\
\hline Business Assistance From Family & -0.050 & -0.066 & 0.096 \\
\hline Business Assistance From Friends & 0.013 & 0.199 & 0.140 \\
\hline Assistance From Other Sources & -0.122 & -0.003 & -0.073 \\
\hline Family Members Business Owners & -0.042 & 0.262 & 0.230 \\
\hline Friends Business Owners & -0.008 & $0.362^{* *}$ & $0.340^{* *}$ \\
\hline Membership in Organizations & 0.007 & 0.045 & -0.027 \\
\hline Number of Organizations & -0.079 & -0.124 & -0.090 \\
\hline PBOE: Job in Same Field & 0.066 & 0.087 & -0.098 \\
\hline PBOE: School Education & -0.076 & -0.166 & -0.283 \\
\hline PBOE: Seminars/Programs & 0.040 & 0.097 & -0.014 \\
\hline PBOE: Hobby/Personal Experience & -0.082 & 0.104 & 0.147 \\
\hline PBOE: Supervisory Experience & 0.094 & $0.348^{* *}$ & 0.279 \\
\hline PBOE: Accounting Experience & -0.062 & 0.179 & 0.193 \\
\hline PBOE: Sales/Marketing Experience & 0.165 & $0.383^{* *}$ & 0.220 \\
\hline
\end{tabular}

$* * p=0.05 \quad * p=0.01$

\section{REFERENCES}

1. Aldrich H., Reese, P.R., and Dubini, P. 1989. Women on the verge of a breakthrough: Networking among entrepreneurs in the United States and Italy. Entrepreneurship and Regional Development, 1, 339-356.

2. Bailey, K.B. 1994. Methods of Social Research, Fourth Edition. New York: The Free Press.

3. Bailey, T. and Waldinger, R. 1991. Primary, secondary and enclave labor markets: A training systems approach. American Sociological Review, 56, 432-445.

4. Bates, T. 1994. An Analysis of Korean-Immigrant-Owned Small-Business Start-Ups with Comparisons to African-American-And Nonminority-Owned Firms. Urban Affairs Quarterly: Volume 30, 227-248.

5. Bates, T. 1973. Black Capitalism: A Quantitative Analysis. London, England: Praeger Publishers.

6. Bates, T. 1986. Characteristics of minorities who are entering self-employment. The Review of Black Political Economy, 31-49.

7. Bates, T. 1991. Commercial bank financing of white- and black-owned small business start-ups. Quarterly Review of Economics and Business, 31, 1, 64-80.

8. Bates, T. 1990. Entrepreneur Human Capital Inputs and Small Business Longevity. The Review of Economics and Statistics: Volume LXXII, 551-559.

9. Bates, T. 1997. Financing Small Business Creation: The case of Chinese and Korean immigrant entrepreneurs. Journal of Business Venturing, 12, 109-124.

10. Bates, T. 1995a. Self-Employment Entry Across Industry Groups. Journal of Business Venturing, 10, 143156.

11. Bates, T. 1995b. Small Businesses Appear to Benefit From State or Local Government's Economic Development Assistance. Urban Affairs Review, Volume 31, 206-225.

12. Bates, T. and Osborne, A. E. 1979. The perverse effects of SBA loans to minority wholesalers. Urban Affairs Quarterly, 15 (1), 87-98.

13. Becker, G. 1993. Human capital : a theoretical and empirical analysis, with special reference to education. Chicago : The University of Chicago Press.

14. Beech, W. 1997. Calling all entrepreneurs. Black Enterprise, Vol.28 (4), 32-34. 
15. Beggs, J. 1995. The institutional environment: Implications for race and gender inequality in the U.S. labor market. American Sociological Review, 60, 612-633.

16. Begley, T. and Boyd, D. 1987. A comparison of entrepreneurs and managers of small business firms. Journal of Management, Volume 13 (1), 99-108.

17. Belcourt, M. 1990. A Family Portrait of Canada's Most Successful Female Entrepreneurs. Journal of Business Ethics, 435-438.

18. Birley, S., Moss, C., and Saunders, P. 1987. Do Women Entrepreneurs Require Different Training? American Journal of Small Business, 27-35.

19. Birley, S. 1989. Female entrepreneurs: Are they really any different? Journal of Small Business Management, 27(1), 32-37.

20. Bitler, M. P., Robb, A. M., and Wolken, J. D. 2001. Financial services used by small businesses: Evidence from the 1998 survey of small business finances. Federal Reserve Bulletin, 87, 183-205.

21. Boucekkine, R., de la Croix, D., and Licandro, O. 2002. Vintage Human Capital, Demographic Trends, and Endogenous Growth. Journal of Economics, 104, 340-375.

22. Bowser, G. 1972. A note on success criteria for minority business. The Review of Black Political Economy, 305-313.

23. Boyd, R. 1991. A contextual analysis of black self-employment in large metropolitan areas, 1970 -1980. Social Forces, 70, 409-430.

24. Brotherton, P. 1999. Get financing now. Black Enterprise, August, 77-84.

25. Brush, C. 1997. Women-Owned Businesses: Obstacles and Opportunities. Journal of Developmental Entrepreneurship Volume 2, 1-24.

26. Brush, C. and Hisrich, R.D. 1991. Antecedent influences on women-owned businesses. Journal of Managerial Psychology, 6(2) 9-16.

27. Burr, Sara G. and Mary Strickland. 1992. Creating a Positive Business Climate for Women: An Approach to Small Business Development. Economic Development Review: Volume 10, 63-70.

28. Buttner, H. \& Rosen, B. 1989. Funding new business ventures: Are decision makers biased against women entrepreneurs? Journal of Business Venturing, 4(4), 249-261.

29. Chaganti, R. and Parasuraman, S. 1996.A Study of the Impacts of Gender on Business Performance and Management Patterns in Small Businesses. Entrepreneurship Theory and Practice, 73-75.

30. Charboneau, F .J. 1981. The woman entrepreneur. American Demographics, 21-23.

31. Chen, G. 1986. Minority business development: An international comparison. The Review of Black Political Economy, 15, 93-111.

32. Choi, T. Y., and Hong, Y. 2002. Unveiling the structure of supply networks: Case studies in Honda, Acura, and DaimlerChrysler. Journal of Operations Management, 20, 469-493.

33. Christopher, J. 1998. Minority business formation and survival: Evidence on business performance and viability. The Review of Black Political Economy, 26 (1), 37-72.

34. Christou, C. 2001. Differential borrowing constraints and investment in human capital. Journal of Macroeconomics, 23, 277-295.

35. Chung, L. Hong, Gibbons, Patrick, T. 1997. Corporate Entrepreneurship: The Roles of Ideology and Social Capital.

36. Chung, L. and Gibbons, P. 1997. Corporate entrepreneurship: The roles of ideology and social capital. Group \& Organization Management, Vol. 22 (1), 10-31.

37. Cianni, M. \& Romberger, B. 1995. Perceived racial, ethnic, and gender differences in access to development experiences. Group and Organization Management, 20(4), 440-459.

38. Collerette, P. and P. Aubry. 1990. Socio-Economic Evolution of Women Business Owners in Quebec. Journal of Business Ethics, 417-422.

39. Cooper, A. C. and Dunkelberg, W. 1987. Entrepreneurial research: Old questions, new answers and methodological issues. American Journal of Small Business, 11-23.

40. Coughlin, J. and Thomas, A. (2002). The Rise of Women Entrepreneurs: People, Processes and Global Trends. Quorum Books, Westport, Connecticut.

41. Covin, J. and Slevin, D. 1994. Corporate entrepreneurship in high and low technology industries: A comparison of strategic variables, strategy patterns and performance in global markets. Journal of Euro Marketing, Vol. 3 (3,4), 99-138. 
42. Cox. T. 1994. Cultural Diversity in Organizations: Theory, Research and Practice. Berrett-Kohler Publishers, San Francisco, CA.

43. Cressy, R. 1996. Are Business Startups Debt-Rationed?. The Economic Journal, 1253-1270.

44. Dannhauser, C. L. 1999. Who's in the Home Office? American Demographics: Volume 21, 50-56.

45. DeCarlo, J. F. and Lyons, P.R. 1979. A comparison of selected personal characteristics of minority and nonminority female entrepreneurs. Journal of Small Business Management, 17, 22-29.

46. Devine, T. 1994. Changes in wage-and-salary returns to skill and the recent rise in female self-employment. Economic Issues For Work and Family, 84, 2, 108-113.

47. Dun and Bradstreet. 2003. Direct Sales and Marketing Catalog: To Help You Grow Your Business.

48. Dunn, T. and Holtz-Eakin, D. 2000. Financial capital, human capital, and the transition to self-employment: Evidence from intergenerational links. Journal of Labor Economics, 18, 282-305.

49. Easter, G. M. 1996. Personal Networks and Postrevolutionary State Building: Soviet Russia Reexamined. World Politics, 48, 551-578.

50. Evans, D. and Leighton, L. 1989. Some empirical aspects of entrepreneurship. The American Economic Review, 519-535.

51. Farkas, George, England, Paula, Vicknair, Keven, Kilbourne, Barbara Stanek. 1997. Cognitive Skill, Skill Demands of Jobs, and Earnings among Young European American, African American, and Mexican American Workers. Social Forces, 75.3.

52. Feagin, J. and Imani, N. 1994. Racial barriers to African American entrepreneurship: An exploratory study. Social Problems, 41, 4, 562-585.

53. Fischer, E. M., Reuber, A. R., \& Dyke, L.S. 1993. A theoretical overview and extension of research on sex, gender and entrepreneurship. Journal of Business Venturing, 8 (2), 151-168.

54. Fratoe, F. 1986. A sociological analysis of minority business. The Review of Black Political Economy, 15, 529.

55. Fratoe, F. 1988. Social capital of black business owners. The Review of Black Political Economy, Spring, 3350.

56. Fukuyama, F. 2002. Social Capital and Development: The Coming Agenda. SAIS Review, 22 , $23-37$.

57. Furry, M. and Lino, M. 1992. An Overview of Home-Based Work: Results From a Regional Research Project. Family Economics Review: Volume 5, 2-8.

58. Furry, M. and Radhakrishna, R. 1992. Home-Based workers in Pennsylvania: Implications for educational programming. Department of Agricultural and Extension Education: The Pennsylvania State University, 2027.

59. Gartner, W. 1985. A conceptual framework for describing the phenomenon of new venture creation. Academy of Management Review, 10(4), 696-706.

60. Gartner, W. and Bhat, S. 2000. Environmental and ownership characteristics of small businesses and their impact on developments. Journal of Small Business Management, Vol. 38 (3), 14-27.

61. Gassenheimer, J., Baucus, D., and Baucus, M. 1996. Cooperative Arrangements among Enterpreneurs : An Analysis of Opportunism and Communication in Franchise Structures. Journal of Business Research, 67-79, 36.

62. Gimeno J., Folta T., Cooper A., and Woo, C. 1997. Survival of the fittest? Entrepreneurial human capital and the persistence of underperforming firms. Administrative Science Quarterly, 42 (4), 750-783.

63. Godoy R., O’Neill K., McSweeney, K., and Wilkie, D. 2000. Human capital, wealth, property rights, and the adoption of new farm technologies: The Tawahka Indians of Honduras. Human Organization, Vol. 59 (2), 222-234.

64. Greller, M. and Stroh, L. 2002. Variations in Human Capital Investment Activity by Age. Journal of Vocational behavior, 61, 109-138.

65. Godoy, R., O’Neill, K., McSweeney, K., \& Wilkie, D. 2000. Human capital, wealth, property rights, and the adoption of new farm technologies: The Tawahka Indians of Homduras. Human Organization, 59, $222-223$.

66. Guaitoli, D. 2000. Human Capital distribution, growth and convergence. Research in Economics, 54, 331350 .

67. Heckman, J. J. 2000. Policies to foster human capital. Research in Economics, 54, 3-56.

68. Hendricks, L. 2001. How Do Taxes Affect Human Capital? The Role of Intergenerational Mobility. Review of Economic Dynamics, 4, 695-735. 
69. Henry, S. 2002. Women Fighting For Venture Capital: Study Cites Entrepreneur Networks. The Washington Post, Feb. 13, E5.

70. Hisrich, R. and Brush, C. 1984. The woman entrepreneur: Management skills and business problems. Journal of Small Business Management, 22, 30-37.

71. Hisrich, R. and Brush, C. 1985. The Woman Entrepreneur: Starting, Financing and Managing a Successful Business. Boston, MA: Lexington Books.

72. Hoffman, C. and Marger, M. 1991. Patterns of Immigrant Enterprise in Six Metropolitan Areas. SSR, Volume 75, 144-157.

73. Hogan, J. M. 2001. Social Capital: potential in family social sciences. Journal of Socio-Economics, 30, 151155 .

74. Horton, H. and De Jong, G. 1991. Black entrepreneurs: A sociodemographic analysis. Research in Race and Ethnic Relations, 6, 105-120.

75. Hout, M. and Rosen, H. 2000. Self-Employment, Family Background and Race. The Journal of Human Resources, Volume 35 (4), 670-692.

76. Humphreys, M. \& McClung, J. 1981. Women entrepreneurs in Oklahoma. Review of Regional Economics and Review, 6(2), 13-20.

77. Hundley, G. 2001. Why women earn less than men in self-employment. Journal of Labor Research, 22 (4), 817-829.

78. Hurtado, A. 1989. Relating to privilege seduction and rejection in the subordination of white women and women of color. Signs: Journal of Women in Culture and Society. Volume 14, 833-855.

79. Hustedde, R. and Pulver, G. 1992. Factors Affecting Equity Capital Acquisition: The Demand Side. Journal of Business Venturing, 7, 363-374.

80. Hyden G. 2001. The social capital crash in the periphery. Journal of Socio-Economics, 30, 161-163.

81. Ibarra, H. 1993. Personal networks of women and minorities in management: A conceptual framework. Academy of Management Review, 18(1), 56-87.

82. Inman, K. 2000. Women's Resources in Business Start-up: A Study of Black and White Women Entrepreneurs. Garland Publishing.

83. Kazemipur, A. and Halli, S. 2001 The changing colour of poverty in Canada. Abdolmohammad Kazemipur, Shiva S Halli. The Canadian Review of Sociology and Anthropology, Vol. 38 (2), 217-239.

84. Kerlinger, F. 1986. Foundations of Behavioral Research. New York: Holt, Rinehart and Winston.

85. Lerner, M. and Almor, T. 2002. Relationship among strategic capabilities and the performance of womenowned small ventures. Journal of Small Business Management, 40 (2), 109-125.

86. Light, I. H. 1979. Disadvantaged minorities in self-employment. International Journal of Comparative Sociology, 20, 31-45.

87. Light I., Bernard, R. and Kim, R. 1999. Immigrant incorporation in the garment industry of Los Angeles. The International Migration Review, 33 (1), 5-25.

88. Loscocco, K. and Leicht, K. 1993. Gender, work-family linkages and economic success among small business owners. Journal of Marriage and Family, 55, 875-887.

89. Loscocco, K. and Robinson, J. 1991. Barriers to women's small business success in the United States. Gender and Society, 5, 4, 511-532.

90. Loscocco K., Robinson J., Hall R. H., and Allen J. K. 1991. Gender and small business success: An inquiry into women's relative disadvantage. Social Forces 70(1), 65-83.

91. Loscocco, K. and Smith-Hunter, A. 2004. Women Home-Based Business Owners: Insights From Comparative Analyses. Women in Management Review, Vol. 19 (3), 164-173.

92. Low, M.B. and Macmillan, I.C. 1988. Entrepreneurship: past research and future challenges. Journal of Management, 14 (2), 139-161.

93. Lucas, J., Youngs, W., Lovaglia, M., and Markovsky, B. 2001. Lines of Power in Exchange Networks. Social Forces, 80.1, 185-214.

94. Marger, M. N. 2001. Social and human capital in immigrant adaptation: The case of Canadian business immigrants. Journal of Socio-Economics, 30, 169-170.

95. Mier, R. and Giloth, R. 1986. Hispanic Employment Opportunities: A Case of Internal Labor Markets and Weak-Tied Social Networks. Social Science Quarterly, Volume 66 (2), 296-309. 
96. Model, S. 1985. A comparative perspective on the ethnic enclaves: Blacks, Italians, and Jews in New York city. International Migration Review, 19(1), 64-81.

97. Molm, L. D., Peterson, G., and Takahashi, N. 2001. The Value of Exchange. Social Forces, 80, 159-184.

98. Moore, D. and Buttner, H. 1997. Women Entrepreneurs: Moving Beyond The Glass Ceiling. Thousand Oaks, California: Sage Publication.

99. Neider, L. 1987. A preliminary investigation of female entrepreneurs in Florida. Journal of Small Business Management, 22-29.

100. Nelton, S. 1999. Women-owned firms lag in winning federal contracts. Nation's Business. March, Volume 87, Issue 3, 12.

101. O’Hare, W. O. and Suggs, R. 1986. Embattled black businesses. American Demographics, April, 27-49.

102. Olson, P. 1997. Are the Floors Less 'Sticky' at Home? Pay Equity in Home-Based Work. Consumer Interests Annual: Issue 43, 239-251.

103. Ong, P. 1981. Factors influencing the size of the black business community. The Review of Black Political Economy, 11, 313-319.

104. Pellegrino, E. and Reece, B. 1982. Perceived formative and operational problems encountered by female entrepreneurs in retail and service firms. Journal of Small Business Management, 15-24.

105. Pendakur, K. and Pendakur, R. 2002. Language as both human capital and ethnicity. The International Migration Review, 36, 147-177.

106. Putnam, R. 1995. Bowling Alone: America's Declining Social Capital. Journal of Democracy. 6.1, 65-78.

107. Renzulli, L., Aldrich, H., \& Moody, J. 2000. Family matters: Gender, networks and entrepreneurial outcomes. Social Forces, 79 (2), 523-546.

108. Riding, A. and Swift, C. 1990. Women business owners and terms of credit: Some empirical findings of the Canadian experience. Journal of Business Venturing, 5(5), 327-340.

109. Robinson-Jacobs, K. 2002. Black-Owned Businesses Blossoming in the Suburbs; Survey: Firms find room to grow in outlying valleys and better access to tech resources in Orange County. The Los Angeles Times, Feb. 21, C1.

110. Russell, C. 1981. The minority entrepreneur. American Demographics, 3, 18-23.

111. Sanders, J. M., \& Nee, V. 1996. Immigrant self-employment: The family as social capital and the value of human capital. American Sociological Review, 61, 231-249.

112. Scherer R., Adams J., Carley, S. and Wiebe, F. 1989. Role Model Performance Effects On Development Of Entreprene. Entrepreneurship Theory and Practice, Vol. 13 (3), 53-73.

113. Scott, W. 1983. Financial performance of minority versus non minority-owned businesses. Journal of Small Business Management, 42-48.

114. Shaver, K. and Scott, L. 1991. Person, Process, Choice: The Psychology of New Venture Creation. Entrepreneurship Theory and Practice, Vol. 16 (2), 23-46.

115. Shim, S. and Eastlick, M. 1998. Characteristics of Hispanic Female Business Owners: An Exploratory Study. Journal of Small Business Management, Volume 36 (3), 18-35.

116. Smart, G. 1998. Management Assessment Methods in Venture Capital: Towards a Theory of Human Capital Valuation.

117. Smith-Hunter, A. 2003. Diversity and entrepreneurship: Analyzing successful women entrepreneurs. Lanham, Maryland: University Press of America.

118. Stearns, T. and Hills, G. 1996. Entrepreneurship and new firm development: A definitional introduction. Journal of Business Research, Vol. 36 (1), 1-5.

119. Steinmetz, G. and Wright, E. 1989. The fall and rise of the petty bourgeoisie: Changing patterns of selfemployment in the postwar United States. American Journal of Sociology, 94, 5, 973.1018.

120. Stevenson, L.A. 1986. Against all odds: The entrepreneurship of women. Journal of Small Business Management, October, 30-36.

121. Taniguchi, H. 2002. Determinants of women's entry into self-employment. Social Science Quarterly, Vol. 83 (3), 875-894.

122. Terpstra, D.E. and Olson, P. 1993. Entrepreneurial start-up and growth: A classification of problems. Entrepreneurship Theory and Practice, Spring, 5-20.

123. Van Auken, H. and Horton, H. 1994. Financing patterns of minority-owned small business. Journal of Small Business Strategy, 31-43. 
124. Van Horn, R. L. and Harvey, M. 1998. The rural entrepreneurial venture: Creating the virtual megafirm. Journal of Business Venturing, 13, 257-274.

125. Watkins, J. M. and Watkins, D. 1986. The female entrepreneur: Her background and determinants of business choice - some British data. Chapter 12 in The Survival of the Small Firm: The Economics of Survival and Entrepreneurship. Edited by James Curran, John Stanworth and David Watkins. England: Publishing Company Limited.

126. White, L. J. 1982. The determinants of the relative importance of small business. The Review of Economics and Statistics, 64, 42-49.

127. Wilkinson, I. and Young, L. 2002. On cooperating: Firms, relations, and networks. Journal of Business Research, 2, 123-132.

128. Wilson, K. and Martin, W. 1982. Ethnic Enclaves: A Comparison of the Cuban and Black Economies in Miami. American Journal of Sociology, 134-157.

129. Woodson, R. 1988. Black America's legacy of entrepreneurship. National Journal of Sociology, 204-224. 


\section{NOTES}

